\title{
Sosialisasi dan Edukasi Pola Hidup Bersih dan Sehat di SDN 01 Mangunharjo Madiun
}

\author{
${ }^{*}$ Lidia Deviga, Radian Arum \\ Stikes Bhakti Husada Mulia Madiun, Indonesia
}

\begin{abstract}
ABSTRAK
Kegiatan pengabdian ini bertujuan untuk memberikan layanan kesehatan dan penyuluhan pentingnya kesehatan diri dan keluarga melalui perilaku hidup sehat, pendidikan kesehatan, menjaga pola makan, dan memberi pemahaman tentang penanganan penyakit degeneratif sederhana yang dapat dilakukan oleh dirinya sendiri atau keluarga. Kegiatan ini tidak hanya memberikan demonstrasi, tetapi juga secara langsung mempraktekan dan mengajari bagaimana cara menjaga pola hidup bersih dan sehat. Antara lain memberi perlengkapan lengkap mandi pada anak anak dan anak langsung mempraktekan cara gosok gigi yang benar, cara mencuci tangan yang benar, cara membuang sampah, dan cara membersihkan diri dari kotoran dan kuman. Kegiatan pengabdian dilakukan di SD Negeri 01 Mangunharjo Madiun. Sampel dari Kegiatan pengabdian ini adalah siswa kelas III dan IV dengan jumlah siswa sebanyak 62 anak. Dari hasil kegiatan penyuluhan dan edukasi pola hidup bersih dan sehat, ternyata masih banyak anak anak yang belum tau bagaimana cara menjaga pola hidup bersih dan sehat. Dan dengan adanya kegiatan ini akhirnya anak anak menjadi paham dan mengerti bagaimana cara menjaga pola hidup bersih dan sehat agar terhindar dari segala penyakit. Karena dengan membiasakan pola hidup bersih, badan akan menjadi sehat,pikiran jernih dan akan mudah untuk belajar sehari hari di sekolah.
\end{abstract}

Kata kunci : Pola Hidup Bersih dan Sehat, Pengetahuan, Tindakan

\begin{abstract}
This activity aimed to provide health services and counseling on the importance of personal and family health in living behavior, health education, maintaining a diet, and providing an understanding of the handling of simple degenerative diseases. This activity not only provides demonstrations, but also directly practices and teaches how to maintain a clean and healthy lifestyle. Among other things, giving children complete bathing equipment and immediately practicing how to brush their teeth properly, how to wash their hands properly, how to dispose of garbage, and how to clean themselves from dirty and germs. This activity at SD Negeri 01 Mangunharjo Madiun. The subjects of this study were 62 students of class III and class IV SDN 01 Mangunharjo Madiun. The result of data analysis, it can be seen that the result of counseling activities and education on clean and healthy lifestyles, there are many children who do not know how to maintain a clean and healthy lifestyle. And with this activity, the children finally know and understand how to maintain a clean and healthy lifestyle to avoid all diseases. Because clean and healthy lifestyle, the body will become healthy, the mind is clear and it will be easy to learn everyday at school.
\end{abstract}

Keyword: The Clean and Healthy Living Behavior, Knowledge and Action 


\section{PENDAHULUAN}

Kesehatan merupakan salah satu kebutuhan hidup manusia yang harus dipenuhi. Bahkan dalam paradigma sehat yang dibangun dalam Visi Indonesia Sehat tahun 2010, kesehatan merupakan hak asasi manusia dan investasi bangsa. Kesehatan merupakan salah satu indikator kualitas sumberdaya manusia suatu masyarakat. Melalui Sistem Kesehatan Nasional, Indonesia berusaha meningkatkan kesehatan masyarakat yang merupakan salah satu indikator Human Development Index (HDI) di mata dunia. Hasil analisis kesehatan nasional Depkes RI, salah satu upaya peningkatan kesehatan masyarakat harus melibatkan masyarakat dengan prinsip pemberdayaan masyarakat. Upaya kesehatan nasional diterjemahkan dalam upaya kesehatan masyarakat (UKM) dan upaya kesehatan perorangan (UKP). UKM meliputi promosi kesehatan, pemeliharaan keehatan, pemberantasan penyakit menular, kesehatan jiwa, penyediaan lingkungan sehat dan sanitasi dasar, perbaikan gizi masyarakat, pengendalian penyakit tidak menular, pengamanan penyediaan farmasi dan alat kesehatan, pengamanan zat aditif berbahaya, narkotika dan psikotropika. Pembentukan kader kesehatan di setiap desa merupakan salah satu langkah strategis dalam mengkampanyekan pola hidup sehat. Pemahaman tentang kesehatan oleh kader kesehatan desa sangat mendukung tugas mereka di masyarakat. Masyarakat juga memerlukan penyegaran dan motivasi perilaku hidup sehat dari sumber informasi yang baru dan kompeten.Kegiatan pembinaan pola hidup sehat ini dilakukan dalam rangka mendukung program peningkatan kesehatan, terutama melalui kepedulian keluarga dalam hal pemenuhan gizi balita, kesehatan balita dan manula, pentingnya hidup bersih, dan perhatian pada penyakit menular/infeksi. perhatian pada penyakit menular/infeksi. Dari analisis situasi dan landasan teori, maka masalah yang dapat dirumuskan adalah : 1) Bagaimana meningkatkan pengetahuan dan sikap terhadap pola hidup bersih dan sehat pada anak anak siswa kelas III dan IV SD Negeri 01 Mangunharjo Madiun? 2) Upaya apa saja yang dapat dilakukan untuk meningkatkan kesadaran gizi, hidup bersih, dan pola perilaku sehat pada anak anak di SD Negeri 01 Mangunharjo Madiun?. Tujuan Kegiatan PPM INI mengacu pada latar belakang dan permasalah di atas, maka kegiatan ini bertujuan untuk :1) Meningkatkan pengetahuan dan sikap terhadap pola hidup bersih dan sehat pada siswa kelas III dan IV SD Negeri 01 Mangunharjo Madiun?. 2) Melakukan upaya kesehatan melalui penyuluhan pola makan sehat, pola hidup, dan perilaku sehat. Manfaat Kegiatan PPM adalah Dengan kegiatan yang dilakukan, mafaat yang diperoleh adalah tumbuh dan berkembangnya pola perilaku hidup sehat melalui pengetahuan tentang gizi keluarga, kebersihan diri dan lingkungan di sekitar SD Negeri 01 Mangunharjo Madiun. Bentuk kegiatan yang dilakukan dalam kegiatan ini adalah Sosialisasi dan edukasi serta pengetahuan dan sikap terhadap pola hidup bersih dan sehat di SD Negeri 01 Mangunharjo Madiun. Sasaran kegiatan ini adalah siswa kelas III dan IV SD Negeri 01 Mangunharjo Madiun . Metode Kegiatan PPM ini untuk mencapai tujuan pengabdian yang direncanakan, kegiatan dilakukan dengan berbagai metode, yaitu: Ceramah/tanya jawab penyuluhan, pemberian angket tentang 
pengetahuan dan sikap terhadap pola hidup bersih dan sehat dan demonstrasi berbagai menu sehat, Demonstrasi gerakan sehat untuk lansia, Pemeriksaan kesehatan Pengobatan. Bakti Sosial pemberian bingkisan Sembako. Hal-hal yang sangat mendukung suksesnya kegiatan ini adalah dukungan dari Kepala sekolah, bapak ibu guru dan staf SD Negeri 01 Mangunharjo, yang sangat membantu dan terbuka untuk sarana dan prasarana yang di gunakan dan disediakan oleh pihak sekolah. Sehingga kegiatan sosialisasi dan edukasi untuk anak anak tentang pola hidup bersih bisa berjalan dengan lancar dan sukses.Target dalam pengabdian masyarakat ini adalah anak anak kelas 2 SD Negeri 01 siswa kelas III dan IV SDN 01 Mangunharjo Madiun. Dalam kegiatan ini diharapkan anak anak tetap mengenal dan tau bagaimana sikap menjaga pola hidup bersih dan sehat. Kegiatan pengabdian masyarakat ini akan menghasilkan luaran berupa pemahaman siswa kelas III dan IV Sdn 01 Mangunharjo Madiun dan anak SD tetap mempelajari dan menerapkan pola hidup bersih dan sehat di lingkungan sehari hari.

\section{METODE}

Berdasarkan permasalahan mitra sebagaimana yang telah diuraikan sebelumnya, maka kegiatan pengabdian Masyarakat kali ini akan dilaksanakan oleh 2 orang dosen di Program Studi Farmasi Stikes Bhakti Husada Mulia Madiun. Metode pelaksanaan kegiatan ini meliputi Praktek lapangan, dengan tujuan:

a. Memberi sosialisasi tentang hidup bersih pada anak anak kelas III dan IV SDN 01 Mangunharjo Madiun

b. Memberi edukasi tentang cara menjaga pola hidup bersih dan sehat di lingkungan sekitar. Dan pemahaman tentang pengetahuan dan sikap terhadap pola hidup bersih dan sehat. Khususnya di area SD Negeri 01 Mangunharjo Madiun.

Pelaksanaan kegiatan pengabdian bagi masyarakat secara umum dapat dilihat pada Gambar 1.

\section{HASIL DAN PEMBAHASAN}

Dari hasil kegiatan sosialisasi dan edukasi pola hidup bersih dan sehat di SD Negeri 01 Mangunharjo Madiun. Dapat diketahui dari koresponden di bawah ini.

Gambaran pengetahuan responden tentang perilaku hidup bersih dan sehat di SDN 01 Mangunharjo Madiun (Tabel 1).

Table 1

Distribusi Tingkat Pengetahuan Responden terhadap Perilaku Hidup Bersih dan Sehat

\begin{tabular}{lcc}
\hline Pengetahuan & $\mathrm{N}$ & $\%$ \\
\hline Baik & 32 & 52 \\
Kurang baik & 30 & 48 \\
Jumlah & 62 & 100 \\
\hline
\end{tabular}

Sumber: Data Diolah 


\begin{tabular}{|c|c|c|c|}
\hline \multirow{4}{*}{$\begin{array}{l}\text { Rendahnya } \\
\text { pengetahuan dan sikap } \\
\text { siswa kelas III dan IV } \\
\text { SDN 01 Mangunharjo } \\
\text { Madiun tentang } \\
\text { bagaimana cara } \\
\text { menjaga pola hidup } \\
\text { bersih dan sehat baik } \\
\text { di sekolah maupun } \\
\text { lingkungan sekitar. }\end{array}$} & $\begin{array}{l}\mathbf{R} \\
\mathbf{A} \\
\mathbf{T}\end{array}$ & $\begin{array}{l}\text { Proses } \\
\text { Advokasi } \\
\text { Komunikasi } \\
\text { Mobilisasi sosial }\end{array}$ & $\begin{array}{l}\text { Output } \\
\text { Adanya dukungan dari } \\
\text { berbagai pihak untuk } \\
\text { mengajarkan kepada } \\
\text { anak anak tentang pola } \\
\text { hidup bersih dan sehat. }\end{array}$ \\
\hline & & & \\
\hline & & $\begin{array}{l}\text { Hasil } \\
\text { Peningkatan pe } \\
\text { ngetahuan dan sik } \\
\text { SDN 01 Mangunl } \\
\text { hidup bersih dan s }\end{array}$ & $\begin{array}{l}\text { haman tentang pe- } \\
\text { siswa kelas III dan IV } \\
\text { o Madiun tentang pola } \\
\text { t. }\end{array}$ \\
\hline & & $\begin{array}{l}\text { Dampak } \\
\text { Keinginan siswa } \\
\text { Mangunharjo M } \\
\text { menjaga pola hidu }\end{array}$ & $\begin{array}{l}\text { as III dan IV SDN } 01 \\
\text { un untuk tetap bisa } \\
\text { ersih sehat }\end{array}$ \\
\hline
\end{tabular}

Gambar 1

Pelaksanaan Kegiatan Pengabdian bagi Masyarakat

Tabel 2

Distribusi Tingkat Pengetahuan Responden terhadap PHBS.

\begin{tabular}{lcc}
\hline Sikap & N & $\%$ \\
\hline Baik & 48 & 76 \\
Kurang baik & 14 & 24 \\
Jumlah & 62 & 100 \\
\hline
\end{tabular}

Sumber: Data Diolah

Berdasarkan tabel 1, tingkat pengetahuan responden tentang perilaku hidup bersih dan sehat (PHBS) menunjukan 32 responden (52\%) memiliki pengetahuan baik dan 30 responden $(48 \%)$ memiliki pengetahuan kurang baik. Jika dibandingkan dengan penelitian yang dilakukan oleh Janus (2014), terhadap tingkat pengetahuan siswa kelas IV,V dan VI terhadap perilaku hidup bersih dan 
sehat menunjukan $80 \%$ berpengetahuan sangat baik. Dan $20 \%$ berpengetahuan kurang baik. Promosi PHBS perlu dimulai sejak usia dini agar menjadi tambahan pengetahuan dan selanjutnya diterapkan dalam kehidupan sehari hari.

Gambaran sikap responden tentang perilaku hidup bersih dan sehat di SDN 01 Mangunharjo Madiun dapat dilihat pada Tabel 2. Berdasarkan tabel 2, tingkat sikap responden tentang perilaku hidup bersih dan sehat (PHBS) menunjukan 47 responden ( 72\%) memiliki pengetahuan baik dan 14 responden (24\%) memiliki pengetahuan kurang baik. Jika dibandingkan dengan penelitian yang dilakukan oleh Yante (2012), tentang tindakan anak asuh harpan kita desa huntu tentang perilaku hidup bersih dan sehat cenderung kurang terbukti 62.5 anak anak panti asuhan memiliki tindakan yang kurang. Perilaku seseorang atau masyarakat tentang kesehatan ditentukan oleh pengetahuan dan sikap. Disamping itu ketersediaan fasilitas, sikap dan perilaku juga akan mendukung dan memperkuat terbentuknya suatu perilaku atau tindakan (Gomo, 2013)

Dari hasil koresponden di atas, maka kegiatan sosialisasi dan edukasi tidak hanya dalam bentuk pemberian angket tentang pengetahuan dan sikap terhadap pola hidup bersih dan sehat saja, melainkan kegiatan ini juga diterapkan secara langsung. Sehingga para siswa kelas III dan IV bisa mempraktekan secara langsung dan bisa mengaplikasikan dalam kehidupan sehari hari. Dan kegiatan praktek ini langsung di pandu oleh dosen STIKES Bhakti Husada Mulia Madiun.

\section{SIMPULAN}

Berdasarkan dari hasil kegiatan pengabdian masyarakat yang bertema Pelaksanaan Sosialisasi dan edukasi pola hidup bersih dan sehat di SD Negeri 01 Mangunharjo, maka dapat ditarik kesimpulan bahwa dengan kegiatan ini antusias peserta didik khususnya kelas 3 SDN 01 Mangunharjo sangat tinggi. Ini ditunjukan dengan antusiasme para anak anak SD Negeri 01 Mangunharjo Madiun dalam mengikuti setiap dan kegiatan menggunakan alat peraga dan di praktekan secara nyata oleh anak-anak. Baik bapak/ibu guru pro aktif dalam menyiapkan sarana dan fasilitas dalam mendukung kegiatan, serta aktif dalam mengkondisikan anak anak SD Negeri 01 Mangunharjo Madiun. Diharapkan dengan adanya kegiatan sosialisasi dan edukasi pola hidup bersih dan sehat di SD Negeri 01 Mangunharjo Madiun pada anak anak kelas 3, pihak sekolah dapat terus meningkatkan dan mengembangkan kegiatan kurikuler dan ekstrakurikuler yang berkaitan dengan kesehatan. Sehingga dapat meningkatkan pengetahuan dan juga kesehatan anak didiknya, dan peserta didik juga bisa menerapkan hidup bersih dan sehat di lingkungan sekitar. Pihak sekolah juga diharapkan mengganti sarana prasarana yang sudah rusak, khususnya di ruang UKS, sehingga bisa digunakan siswa dalam penerapan pola hidup bersih dan sehat. Sedangkan untuk para siswa diharapkan dapat menerapkan bagaimana cara menggosok gigi yang benar, cara merawat kuku, cara membersihkan tangan menggunakan sabun yang benar dan bias diaplikasikan dalam kehidupan sehari hari. 


\section{DAFTAR PUSTAKA}

Busising, R. 2010. Gambaran Perilaku Siswa Sekolah Dasar Negeri 1 Motoboi Kecil Tentang Perilaku Hidup Bersih dan Sehat. Skripsi FKM UNSRAT: Manado.

Wowor, S. 2013. Gambaran Perilaku Hidup Bersih dan Sehat pada anak sekolah dasar, GMIM Lemoh. Universitas Sam Ratulangi: Manado. Jurnal Media Kesehatan

Yante, L. 2012. Gambaran Tentang Perilaku Hidup Bersih dan Sehat (PHBS) pada anak di desa Huntu Bualango. Universitas Negeri Gorontalo. Jurnal Public Health Journal Vol.1/No.1/2012

Proverawati, A dan Rahmawati, E.2012. Perilaku hidup bersih dan sehat (PHBS). Yogyakarta: NuhaMedika.

Departemen kesehatan RI.2013. Hasil Riset Kesehatan Dasar Indonesia 2013.

Gomo ,M. J. 2013. Gambaran Perilaku Hidup Bersih dan Sehat (phbs) Sekolah pada Siswa di SMPN 8 Manado. Fak Kedokteran. UNsRAT: Manado. Jurnal eBiomedik (Ebm). Vol.1/No.1/Maret.2013

Allen, Harold B. 1990. As A second Language. New York: McGraw-Hill Book Company.

Krashen. 1985 ; Oxford , 1998 : Strevens, 1997.

Barnhart, Cyntia A. 2008. The Facts On File Students Dictionary of American English.

Penny UR. 1991. A Course in Language Teaching: Practice and Theory, Cambridge University Press.

Azhar Arsyad, 1997. Media Pembelajaran. Jakarta: Raja Grafindo Persada. 